\title{
Journal of Tourismology
}

Submitted: 21.09 .2019

Revision Requested: 12.10 .2019

Last Revision Received: 02.01.2020

RESEARCH ARTICLE

Accepted: 18.01 .2020

Published Online: 10.03 .2020

\section{Applying Flow Theory to the Online Booking Experience: The Role of Utilitarian and Hedonic Features}

Engin Tengilimoglu1 ${ }^{1}$, Azize Hassan² ${ }^{(1)}$

\begin{abstract}
The transformations experienced in the tourism industry along with developing internet technologies are bringing out new distribution channels. The presentation of tourism products through these channels has also been rapidly accepted by the tourists. Online travel sales exceeding 690 billion dollars together with developing mobile payment options have made online purchasing behaviors an important issue. Although Flow Theory had been previously used in the fields such as adventure and sports, in the course of time it has started to be used also for understanding online consumer behaviors and it was seen that it has positive effects like trust, and e-loyalty in users. Therefore, determination of the factors that will provide consumers with flow experience in online environments, has also become an important issue. In this study, the features of a booking site that will provide consumers with flow experience were examined and which factors are more effective in the flow theory was searched. Consequently, it was determined that the flow experience is affected by utilitarian and hedonic features offered to consumers. Additionally, it was also observed that hedonic features offered to the consumers during the purchasing process affects the flow experience more than utilitarian features.
\end{abstract}

\section{Keywords}

Flow theory, Online rezervation, Online purchase behavior, Utilitarian and hedonic features

1 Correspondence to: Engin Tengilimoglu (Ress. Asst.), Selcuk University, Faculty of Tourism, Department of Tourism Management, Konya, Turkey. E-mail: entengilimoglu@selcuk.edu.tr ORCID: 0000-0001-7080-6147

2 Azize Hassan (Prof. Dr.), Hacı Bayram Veli University, Faculty of Tourism, Department of Travel Management and Tourism Guidance, Ankara, Turkey. E-mail: azize@gazi.edu.tr ORCID: 0000-0003-2509-1415

To cite this article: Tengilimoglu, E., \& Hassan, A. (2020). Applying flow theory to the online booking experience: The role of utilitarian and hedonic features. Journal of Tourismology, 6(1), 1-12. https://doi.org/10.26650/jot.2020.6.1.0010 


\section{Introduction}

Developing technology has led to major transformations also in the tourism industry as in every field of life from past to present. One of the most obvious examples of this interaction between technology and tourism is the changes which have resulted from the central rezervation systems (Sabre, Amadeus, Galileo etc.) that appeared in the industry during the 1980s. A series of elements from the business administration practices to the industry's structure together with global distribution channels have been reshaped during this process (Buhalis and Law, 2008). Afterwards, internet technologies, which were developed and became widespread, have offered unparalleled opportunities to both consumers and suppliers by affecting deeply once again the tourism industry. Evolving internet technologies have allowed suppliers to reach directly to the consumers by filling the gap between the suppliers and consumers and have weakened the loyalty to traditional travel agencies. Online travel agencies (booking.com, expedia.com etc.), which emerged towards the end of the 1990s, have substantially changed the touristic purchasing behaviors (Amaro and Duarte, 2015; Buhalis and Law, 2008) and have made it compulsory for traditional travel agencies to employ developing internet technologies in terms of their survival (Kamau, 2015). Now online distribution channels have reached an important point in the tourism industry. Nowadays, online travel purchasing has reached 694 billion dollars globally owing to the improved mobile payment options and online travel agencies and this figure is expected to rise to 931 billion dollars until 2022 (Emarketer, 2018). This increase in online travel sales and the predictions that this increase will continue have ensured both the industry and academic studies focus on this field by causing the increase of this importance attached to this issue. While the internet has been gaining importance as a new marketing channel that gradually increases the market share in terms of the industry, has both caused a transformation in traditional travel agencies (Kamau, 2015) and paved the way for the emergence of new online travel agencies (Liu and Park, 2015). Meanwhile in the academic circles, with a growing number of studies (Buhalis and Law, 2008), both existing theories (Flow Theory, Planned Behavior Theory) have been adapted to the online distribution channels and new theories (Online Shopping Acceptence Model) have been put forward in line with the developing technologies.

Today, online distribution channels emerged with internet technologies, have resulted in large conversions gradually in the tourism industry, which are being rapidly accepted (Muneta at all, 2013) by both consumers and suppliers (Nusair and Parsa, 2011). Bilgihan (2012) states that tourism products is one of the products which are mostly accepted by consumers among the products sold over the internet. Meanwhile, it is expressed in a study conducted by Tripadvisor (2016) that $86 \%$ of the travelers prefer online resources for accommodation (Tripbarometer, 2016). 
The rise of online channels to a significant point in the tourism industry has brought up the subjects such as online consumer behaviours (Amaro and Duarte, 2015) online comments (Tengilimoğlu at all, 2017; Çuhadar at all, 2018; Sunar at all, 2018; Ak and Dinçer, 2019), hotel scoring systems (Liu and Park, 2015; Akgöz and Tengilimoğlu, 2015), ease of use, quality and functionality of the websites (Liu and Zhang, 2014), user security and privacy (Schubert and Henseler, 2018). Moreover, the online purchase experience offered to the consumers has also been one of the most frequently emphasized issues (Novak at all, 2000; Obada, 2013; Özkara at all, 2017) and it has been associated with concepts like online purchasing intent, e-loyalty and trust (Bilgihan, 2012).

Bilgihan (2015) remarks that $24 \%$ of annual online revenue is lost globally because of poor online customer experiences while stressing the importance of online booking experience for consumers. The influence of online purchasing experience on consumers' subsequent purchasing behaviors was extensively examined and various studies have supported the opinion that positive experiences create trust, re-purchases and loyalty (Koufaris, 2002; Hsu at all, 2013; Bilgihan and Bujisic, 2015; Özkara at all, 2017). While this kind of results enables marketers to have interest in this issue (Lopez and Ruiz, 2015), it has also caused the increase of studies explaining the online purchasing behaviors in academic circles (Buhalis and Law, 2008; Noort at all, 2012). Right at this point, the Flow Theory developed by Csikszentmihalyi in 1975 started to be used also in order to examine the interaction with human and computer in online environments (Hoffman and Novak, 1996; Bilgihan, 2012; Obada, 2013) as well as subjects such as sports, adventure and education (Barış, 2015). It is stated in many studies that the flow theory is a convenient instrument to understand the online consumer behaviors (Hoffman and Novak, 1996; Novak at all, 2000; Hsu at all, 2013; Esteban at all, 2014). The shopping experience in online environments expresses the purchasing process realized between the website and consumer. Meanwhile, the flow experience during this process can be expressed by an engrossing and hedonic experience (Bilgihan, 2012) when the consumers behave with full interest and concentration.

Novak et al. (2000) expresses that it is necessary to compose websites allowing flow experience in order to convince consumers to purchase in online environments. Bilgihan (2015) remarks that consumers give importance to both hedonic and utilitarian features which will provide them with flow experience during the online purchasing process. Hedonic and utilitarian features of the websites are the most frequently addressed subjects in the studies conducted on online shopping (Nusair and Parsa, 2011; Bilgihan, 2012; Lopez and Ruiz, 2015). Meanwhile, this study examines the effect of the consumers' preference reasons of online channels which are determined by Liu and Zhang (2014) for hotel reservation, booking websites' hedonic 
based features which have been composed by Bilgihan (2012) and consumers' web skills described by Koufaris (2002) in his study on the flow experience by means of the perceived usefulness, shopping enjoyment and ease of use.

\section{Hypotheses Development and Theoretical Research Model}

Online travel sales with an increasingly growing share in the market makes the comprehension of consumers' online shopping behaviour an important issue. One of the theories preferred for the purpose of understanding online consumer behaviour is the Flow Theory (Hoffman and Novak, 1996; Novak at all, 2000). The word "flow" is used to describe a state of mind that is sometimes experienced by people who are completely engaged in some activity. One example of flow is when a user is shopping online and achieves a state of mind where nothing else matters but the shopping; you engage in online shopping with total involvement, concentration and enjoyment. You are completely and deeply immersed in it. Many people report this state of mind when browsing webpages, chatting online and word processing (Bilgihan, 2015:671). Consumers' flow experience during the online shopping process is affecting their purchasing behaviors, e-trust and e-loyalty (Koufaris, 2002; Hsu at all, 2013; Bilgihan and Bujisic, 2015; Özkara at all, 2017). These kind of results shown by the studies make the flow experience an important study field about online shopping.

It is seen that the consumers' flow experience in online environments is related to both hedonic and utilitarian features when the studies and the definitions about the flow experience are examined (Koufaris, 2002; Nusair and Parsa, 2011; Bilgihan, 2012; Lopez and Ruiz, 2015). Besides, the skills of an individual and the difficulty of the work are among the factors affecting the flow experience (Koufaris, 2002). In this context, users' Flow Experience can be explained by dimensions of the Perceived Usefulness through the influence of utilitarian features of the websites, the Shopping Enjoyment through the influence of hedonic features of the websites and the Perceived Ease of Use through the influence of payment facilities offered and the web skills of an individual. The following study model has been developed on the basis of this thought.

Generated hypothesis are listed below.

H1: The perceived usefulness positively affects the flow experience of consumers.

H2: The perceived ease of use positively affects the flow experience of consumers.

H3: The perceived hedonic level positively affects the flow experience of consumers. 


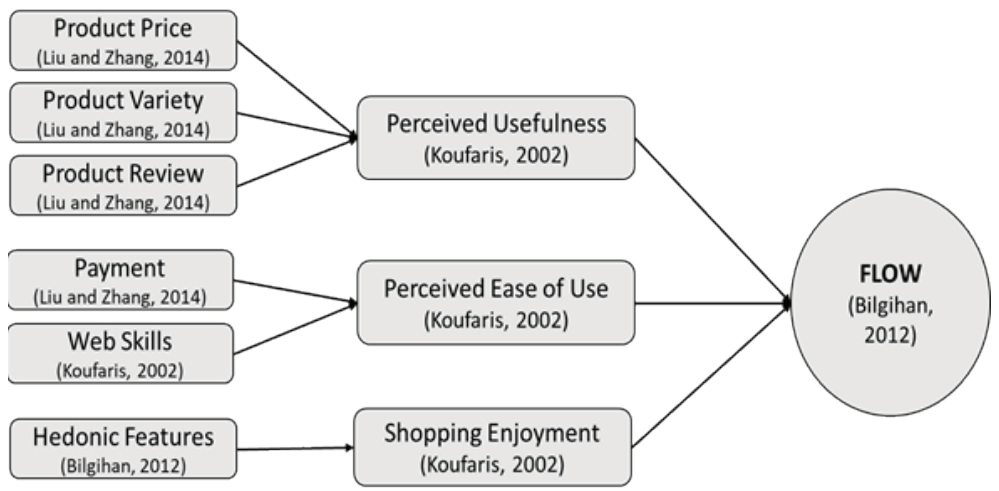

Figure 1. Research model

\section{Method}

The purpose of this study is to examine which features of booking sites are more important for the flow experience in online environments. In this context, previous studies have been examined and it was seen that the flow experience is usually associated with utilitarian and hedonic features of booking websites (Bilgihan, 2015). In addition, it is also stated that the ease of use and web skills are effective variables in the flow experience (Koufaris, 2002). In this context, a questionnaire was in compliance with the purpose of the study. Product Price, Product Variety, Product Reviews and Payment scales in the questionnaire have been taken from the study conducted by Liu and Zhang in 2014. Hedonic Features scales relating to the Flow Experience have been obtained from the study of Bilgihan (2012). Finally, Web Skills, Perceived Usefulness, Shopping Enjoyment and Perceived Ease of Use scales have been taken from Koufaris (2002).

The target respondents of the study consists of the people who have already made an hotel booking online. The questionnaire was on google in December 2018. Compliance with target respondents, the questionnaire was sent via social media to individuals and groups who may be interested in online hotel booking. It is recommended to send the survey via internet for the purpose of reaching the target respondents if they are internet users (Liu and Zhang, 2014; Bilgihan, 2015). The first question of the questionnaire is "Have you ever made an online hotel booking?". The participants, who answered 'yes' to this question, continued to reply to the next questions and if they answered 'no' then the following questions were not asked to them. Thus, it has been ensured that only the people who had experience on this subject participated in this survey. 
Table 1

Online Booking Experience

\begin{tabular}{cccc}
\hline Question & Answer & N & Percent \\
\hline Have you ever made an online hotel booking? & Yes & 139 & 76,0 \\
\hline Total & No & 44 & 24,0 \\
\hline
\end{tabular}

It is presented in the table whether the participants have already experienced online booking by the number of people. Based on the results, $76 \%$ of 183 participants, namely 139 participants have made online booking, and $24 \%$ of 183 subjects, namely 44 participants have not made. 44 participants who have not online booking experience were excluded from the study for the subsequent parts. Demographic characteristics with regard to 139 respondants who have experienced online booking are given below.

Table 2

Demographic Characteristics

\begin{tabular}{lllc}
\hline Question & Answer & N & Percent \\
\hline Are you male or female? & Male & 87 & 62,6 \\
\hline & Female & 51 & 37,4 \\
\hline What is your age? & 24 or Younger & 25 & 18,0 \\
& $25-34$ & 56 & 40,3 \\
& $35-44$ & 37 & 26,6 \\
& $45-55$ & 19 & 13,6 \\
& 55 or Older & 2 & 1,4 \\
\hline What is your level of education? & Primary School & 1 & 0,7 \\
& High School & 8 & 5,8 \\
Please indicate your occupation. & Associate degree $(2$ year) & 10 & 7,2 \\
& Bachelor's Degree (4 year) & 59 & 42,4 \\
& Postgraduate & 59 & 42,4 \\
\hline
\end{tabular}

Male participants comprises more than half $(62 \%)$ of the people who participated in the research. The most intensive age range is $25-34(40 \%)$ of the people who participated in the survey. With regard to education, the participants who have Bachelor's Degree (42\%) and Masters' Degree (42\%) stands out. Academicians (33\%) are prominent in terms of occupation. It is observed that the participants who have an income of $5001 \mathrm{TL}$ and above (39\%) with regard to income level distribution depending on the occupation is quite high. 
In the study, the structural equation model was established by employing the Smart PLS package program. It is set forth that the sampling size of 10 times of the proposition number of the variable having a maximum proposition number in the PLS path model is sufficient (Hair et al, 2014). In our study, the variable which has the highest proposition is Hedonic features with 7 propositions. Therefore, the sampling number must be at least 70 according to this calculation. In our study, the sampling size is 139 .

\section{Confirmatory Factor Analysis, Reliability and Validity Tests}

It is recommened to carry out Confirmatory Factor Analysis in PLS, to examine Composite Reliability and AVE values for the purpose of evaluation of results and determination of reliability and validity of the structural equation model (Hair ar all, 2014). Confirmatory Factor Analysis results, Composite Reliability and Average Variance Extracted values are shown in the table below.

A calculation above 0.7 is generally accepted for item loads. When the table above is examined, it is seen that all item loads have been calculated higher than the acceptable value of 0.7 .

It is more appropriate to use Composite Reliability for measurement of PLS internal consistency reliability. The values between 60 and 70 is adeaqute for composite reliability for the studies. It is seen in the table above that composite reliability values have been calculated higher than the generally accepted rates. The other matter that must be taken into consideration after the internal consistency test is AVE values. AVE values are expected to be higher than 0,5 . When the table is examined, it is seen that this condition is provided, too.

Lastly, Discriminant Validity values have been examined. The correlation with relevant variables of the values representing the square roots of AVE values is expected to be higher than the correlations with other variables. Upon reviewing of the values, it was seen that the study provided Discriminant Validity.

\section{Findings and Conclusion}

In the study, the model was run after the reliability and validity tests were done. Structural equation model involves developing measurement models to define latent variables and then establishing relationships or structural equations among the latent variables. (Bilgihan, 2015). The latent variables measured and the values expressing their interrelation are given in the following research model.

The values in the middle of the circles in the model represent R2s and give the description ratio of relevant dimension. In this context, $38 \%$ of the change appeared in the Perceived Usefulness dimension is expressed by Product Price, Product Variety 
Table 3

Item Loadings and Reliability Scores

\begin{tabular}{|c|c|c|c|c|}
\hline Factors & Items & Factor Loadings & $\begin{array}{l}\text { Composite } \\
\text { Reliability }\end{array}$ & AVE \\
\hline \multirow{6}{*}{ Flow Experience } & F1 & 0.860 & \multirow{6}{*}{0,913} & \multirow{6}{*}{0.638} \\
\hline & $\mathrm{F} 2$ & 0.831 & & \\
\hline & F3 & 0.812 & & \\
\hline & $\mathrm{F} 4$ & 0.826 & & \\
\hline & F5 & 0.781 & & \\
\hline & F6 & 0.703 & & \\
\hline \multirow{4}{*}{ Shopping Enjoyment } & SE1 & 0.876 & \multirow{4}{*}{0.945} & \multirow{4}{*}{0.812} \\
\hline & SE2 & 0.914 & & \\
\hline & SE3 & 0.916 & & \\
\hline & SE4 & 0.897 & & \\
\hline \multirow{3}{*}{ Perceived Usefulness } & PU1 & 0.793 & \multirow{3}{*}{0.871} & \multirow{3}{*}{0.693} \\
\hline & PU2 & 0.861 & & \\
\hline & PU3 & 0.842 & & \\
\hline \multirow{4}{*}{ Peceived Ease of Use } & PEU1 & 0.869 & \multirow{4}{*}{0.934} & \multirow{4}{*}{0.779} \\
\hline & PEU2 & 0.872 & & \\
\hline & PEU3 & 0.919 & & \\
\hline & PEU4 & 0.870 & & \\
\hline \multirow{7}{*}{ Hedonic Features } & HF1 & 0.702 & \multirow{7}{*}{0.905} & \multirow{7}{*}{0.577} \\
\hline & HF2 & 0.789 & & \\
\hline & HF3 & 0.731 & & \\
\hline & HF4 & 0.703 & & \\
\hline & HF5 & 0.811 & & \\
\hline & HF6 & 0.825 & & \\
\hline & HF7 & 0.767 & & \\
\hline \multirow{3}{*}{ Web Skills } & WS1 & 0.896 & \multirow{3}{*}{0.892} & \multirow{3}{*}{0.734} \\
\hline & WS2 & 0.865 & & \\
\hline & WS3 & 0.807 & & \\
\hline \multirow{2}{*}{ Payment } & P1 & 0.860 & \multirow{2}{*}{0.879} & \multirow{2}{*}{0.784} \\
\hline & $\mathrm{P} 2$ & 0.910 & & \\
\hline \multirow{2}{*}{ Product Price } & PP1 & 0.815 & \multirow{2}{*}{0.776} & \multirow{2}{*}{0.635} \\
\hline & PP2 & 0.778 & & \\
\hline \multirow{3}{*}{ Product Review } & PR1 & 0.937 & \multirow{3}{*}{0.868} & \multirow{3}{*}{0.768} \\
\hline & PR2 & 0.811 & & \\
\hline & PR3 & 0.937 & & \\
\hline & PV1 & 0.707 & & \\
\hline Product Variety & PV2 & 0.836 & 0854 & 0505 \\
\hline Product variety & PV3 & 0.775 & 0.854 & 0.595 \\
\hline & PV4 & 0.761 & & \\
\hline
\end{tabular}

and Product Reviews. Meanwhile, 58\% of the Perceived Ease of Use is expressed by Payment and users' Web Skills. And 34\% of the Shopping Enjoyment is expressed by Hedonic Features of the website. Finally, $41 \%$ of the change appeared in the flow experience is expressed by Perceived Usefulness, Perceived Ease of Use and Shopping Enjoyment. The path coefficients expressing the interrelation of variables and $p$ values showing whether these coefficients are significant, are shown in the following table.

The table above shows the coefficients of the paths generated and $p$ values of these coefficients. Upon reviewing of the table, it is observed that two of the ten paths generated have no significant effect and other eight paths are significant. 
Table 4

Discriminant Validity

\begin{tabular}{|c|c|c|c|c|c|c|c|c|c|c|}
\hline Factors & $\mathbf{F}$ & SE & PU & PEU & HF & WS & $\mathbf{P}$ & PP & PR & PV \\
\hline Flow & 0.799 & & & & & & & & & \\
\hline Shopping Enjoyment & 0.556 & 0.901 & & & & & & & & \\
\hline Perceived Usefulness & 0.527 & 0.508 & 0.833 & & & & & & & \\
\hline Perceived Ease of Use & 0.466 & 0.369 & 0.643 & 0.883 & & & & & & \\
\hline Hedonic Features & 0.582 & 0.584 & 0.680 & 0.607 & 0.760 & & & & & \\
\hline Web Skills & 0.488 & 0.278 & 0.448 & 0.725 & 0.515 & 0.857 & & & & \\
\hline Payment & 0.184 & 0.353 & 0.446 & 0.415 & 0.503 & 0.259 & 0.886 & & & \\
\hline Product Price & 0.418 & 0.338 & 0.445 & 0.424 & 0.521 & 0.458 & 0.329 & 0.797 & & \\
\hline Product Review & 0.402 & 0.386 & 0.549 & 0.693 & 0.597 & 0.551 & 0.572 & 0.321 & 0.876 & \\
\hline Product Variety & 0.410 & 0.216 & 0.462 & 0.546 & 0.558 & 0.613 & 0.365 & 0.578 & 0.533 & 0.771 \\
\hline
\end{tabular}

\section{Tablo 5}

Hypotheses, Path Coefficients and P Values

\begin{tabular}{lccccc}
\hline Hypotheses & $\begin{array}{c}\text { Path } \\
\text { Coefficent }\end{array}$ & $\begin{array}{c}\text { Std. } \\
\text { Dev. }\end{array}$ & $\begin{array}{c}\text { T } \\
\text { Value }\end{array}$ & $\begin{array}{c}\text { P } \\
\text { Value }\end{array}$ & Result \\
\hline H: Product P. $\rightarrow(+)$ Perceived U. & 0.258 & 0.076 & 3.422 & 0.001 & Yes \\
H: Product V. $\rightarrow(+)$ Perceived U. & 0.091 & 0.094 & 0.969 & $\mathbf{0 . 3 3 3}$ & No \\
H: Product R. $\rightarrow(+)$ Perceived U. & 0.417 & 0.081 & 5.139 & 0.000 & Yes \\
H: Payment $\rightarrow(+)$ Peceived Ease of U. & 0.244 & 0.075 & 3.268 & 0.001 & Yes \\
H: Web S. $\rightarrow(+)$ Peceived Ease of U. & 0.662 & 0.054 & 12.297 & 0.000 & Yes \\
H: Hedonic F. $\rightarrow(+)$ Shopping E. & 0.584 & 0.066 & 8.842 & 0.000 & Yes \\
H1: Perceived U. $\rightarrow(+)$ Flow & 0.215 & 0.109 & 1.965 & 0.040 & Yes \\
H2: Peceived Ease of U. $\rightarrow(+)$ Flow & 0.189 & 0.101 & 1.869 & $\mathbf{0 . 0 6 2}$ & No \\
H3: Shopping E. $\rightarrow(+)$ Flow & 0.377 & 0.075 & 5.040 & 0.000 & Yes \\
\hline
\end{tabular}

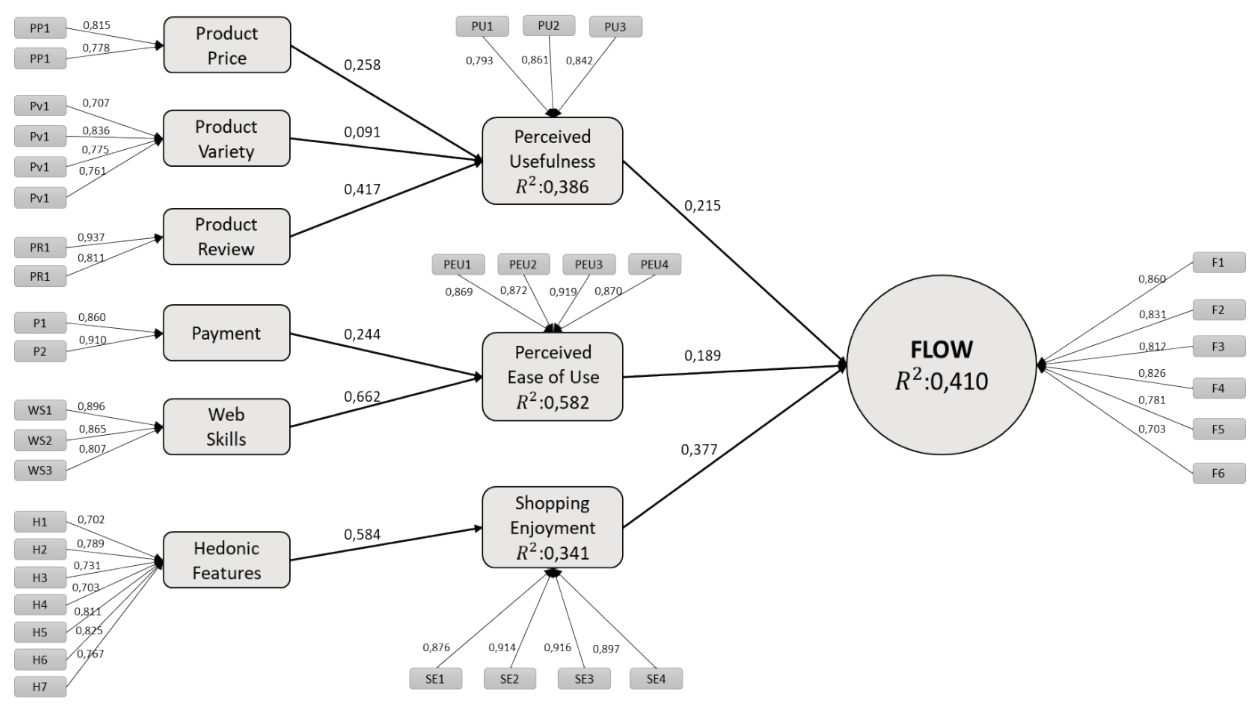

Figure 2. Results of model 
At the same time, path coefficients express the impact level of a variable on the respective variable. In this context, it is possible to determine which variables have a larger effect on the flow experience through the coefficients of the paths going the flow experience. When the coefficients are examined, it is seen that the Perceived Usefulness has been calculated as 0,215 , the Perceived Ease of Use as 0,189 and the Shopping Enjoyment as 0,377. It was stated that the insignificance of the coefficient calculated for the perceived ease of use was due to the calculation of $p$ value above 0,05 . Therefore this coefficient value is not significant. However, the $\mathrm{p}$ values (path coefficient) calculated for the Shopping Enjoyment $(0,000)$ and Perceived Usefulness $(0,040)$ shows its significance. When the coefficients are compared, it is seen that the Shopping Enjoyment $(0,377)$ has greater impact than the Perceived Usefulness $(0,215)$. In this context, the hedonic level perceived by users on booking websites becomes an issue more important than the perceived usefulness with regard to the flow experience. This result has also been supported by similar studies (Bilgihan, 2015). Hedonic features $(0,584)$ of the websites affect the Shopping Enjoyment level. In this context, it gains importance for booking websites to turn the booking process into a more entertaining activity by attaching importance to hedonic features in terms of providing users with the flow experience.

Availability of some factors giving benefits (price, comparison, product variability etc.) to the users, may enable consumers to prefer a certain channel (Liu and Zhang, 2014) but it is only possible to create loyalty in consumers towards a specific channel particularly in the environments containing computer human interactions and covering a certain process such as researching, receiving information, comparison like online booking purchases through offering some features which entertain (Bilgihan, 2012) the users (consumers). At this point, the websites' hedonic features, which express as well as the offering way of utilitarian features to consumers by online channels gain importance.

Utilitarian features which are quite close to each other are presented by many alternatives in online booking websites but the websites' hedonic features can be seen as an important strategy for the purpose of differing with regard to uniqueness. In consideration of the impact of the hedonic features, which are also supported by this study, on the flow experience and the positive effects of the flow experience, which are showed by former studies such as e-loyalty, e-purchasing and brand equity; the hedonic features of the websites are a matter of subject that must be highlighted with regard to online booking. In this study, the importance of hedonic features of the booking websites were emphasized, and its effect on the flow experience was mentioned through the shopping enjoyment. 


\section{References}

Ak, S., \& Dincer, M. Z. (2019). Investigation of Consumer Reviews on Social Media for Five-Star Hotel Enterprises in Istanbul: A Case of TripAdvisor. Paper presented at the 18th Traditional Tourism Symposium, Istanbul, Turkey. Proceedings of the Journal of Tourismology, 5(2), $171-183$

Akgöz, E., \& Tengilimoğlu, E. (2015). Online müşteri değerlendirmelerinin, tesis özellikleri açısından incelenmesi; Booking.com örneği. 16. Ulusal Turizm Kongresi, Çanakkale, 145-163.

Amaro, S., \& Duarte P. (2015). An integrative model of consumers' intentions to purchase travel online. Tourism Management, (46), 64-79.

Barış, G. (2015). Optimal Deneyimler Psikolojisi. In Yağcı, M. İ. \& Çabuk S. (Ed.), Pazarlama Teorileri, (pp. 251-264). MediaCat, İstanbul.

Bilgihan A., Nusair K., Okumus F., \& Cobanoglu, C. (2015). Applying flow theory to booking experiences: An integrated model in an online service context. Information \& Management, (52), 668-678.

Bilgihan, A. (2012). The role of flow in creatıng e-loyalty: the case of online hotel booking websites. Doctor of Philosophy Dissertation, University of Central Florida, Orlando, Florida.

Bilgihan, A., \& Bujisic, M. (2015). The effect of website features in online relationship marketing: A case of online hotel booking. Electronic Commerce Research and Applications, (14), 222-232.

Buhalis, D., \& Law, R. (2008). Progress in information technology and tourism management: 20 years on and 10 years after the Internet-The state of eTourism research. Tourism Management, (29), 609-623.

Çuhadar, M. ve Köseoğlu, S. \& Gültepe, Ö. (2018). Isparta ilindeki konaklama işletmelerine yönelik çevrimiçi müşteri değerlendirmelerinin incelenmesi: Tripadvisor örneği. Süleyman Demirel Üniversitesi, İktisadi ve İdari Bilimler Fakültesi Dergisi, 23(1), 227-239.

Emarketer (2018). Global digital travel sales 2018. https://www.emarketer.com/content/globaldigital-travel-sales-2018. Access Date; 10.12.2018.

Esteban, I., Francisco, M., Martínez, J., David L., \& Rodrigez A. I. (2014). The concept of flow in online consumer behavior. In F. J. Martinez-Lopez (Ed.), Handbook of Strategic e-Business Management (pp. 371-402). Springer-Verlag Berlin Heidelberg.

Guo, Y. M., \& Poole, M. S. (2009). Antecedents of flow in online shopping: A test of alternative models. Info Systems Journal, (19), 369-390.

Hair, J. F., Hult, G. T., Ringle, C. M., \& Sarstedt M. (2014). A Primer On Partial Least Squares Structural Equation Modeling (PLS-SEM), London, SAGE Publications.

Hoffman, D. L., \& Novak, T. P. (1996). Marketing in hypermedia computer-mediated environments: conceptual foundations. The Journal of Marketing, 60(3), 50-68.

Hsu, C. L., Wu, C. C., \& Mu-Chen C. M. C. (2013). An empirical analysis of the antecedents of e-satisfaction and e-loyalty: focusing on the role of flow and its antecedents. Information Systems E-Bussiness Management, (11), 287-311. 
Kamau, J. P. W. (2015). Travel agencies response to internet evolution in Nairobi country: an analysis of competitive strategies. Doctor of Philosophy Dissertation, Kenyatta University.

Koufaris, M. (2002). Applying the technology acceptance model and flow theory to online consumer behavior. Inf. Syst. Res., 13(2), 205-223.

Liu, J. N. K., \& Zhang, E. Y. (2014). An investigation of factors affecting customer selection of online hotelbooking channels. International Journal of Hospitality Management, (39), 71-83.

Liu, Z., \& Park, S. (2015). What makes a useful online review? Implication for travel product websites. Tourism Management, (47),140-151.

Lopez, I., \& Ruiz, S. (2011). Explaining website effectiveness: The hedonic-utilitarian dual mediation hypothesis. Electronic Commerce Research and Applications, (10), 49-58.

Muneta, A., Elena, M., \& Andrea, O. L. (2013). ICT Impact on tourism industry. International Journal of Management Cases, 15(2), 87-98.

Noort, G. V., Voorveld, H. A. M., \& Reijmersdal, E. A. V. (2012). Interactivity in brand web sites: cognitive, affective, and behavioral responses explained by consumers' online flow experience. Journal of Interactive Marketing, (26), 223-234.

Novak, T. P., Hoffman, D. L., \& Yung, Y. F. (2000). Measuring the customer experience in online environments: a structural modeling approach. Marketing Science, 19(1), 22-42.

Nusair, K., \& Parsa, H. G. (2011). Introducing flow theory to explain the interactive online shopping experience in a travel context. International Journal of Hospitality Tourism Administration, (121), 1-20.

Obada, D. R. (2013). Flow theory and online marketing outcomes: a critical literature review. Procedia Economics and Finance, (6), 550-561.

Ozkara, B. Y., Ozmen, M., \& Kim J. W. (2017). Examining the effect of flow experience on online purchase: A novel approach to the flow theory based on hedonic and utilitarian value. Journal of Retailing and Consumer Services, (37),119-131.

Schuberth, T. M. F., \& Henseler, J. (2018). PLS path modeling-a confirmatory approach to study tourism technology and tourist behavior. Journal of Hospitality and Tourism Technology, 9(3), 249-266.

Sunar, H., Gökçe, F. ve Sürücü, A. Ö. (2018). Hatay'ın turizm değerlerinin online müşteri deneyimleri aracılığıyla incelenmesi. Journal of Recreation and Tourism Research, 5(4), 63-71.

Tengilimoğlu, E., Göral, R. ve Akgöz, E. (2017). Olumlu ve olumsuz geri bildirimlerin memnuniyet düzeylerine göre incelenmesi: Booking.com örneği. 18. Ulusal Turizm Kongresi, Mardin, 556566.

TripAdvisor (2016). TripBarometer, Traveler Trends \& Motivations Global Findings. 